Wolfgang Jonas

070223

\title{
Design Research and its Meaning to the Methodological Development of the Discipline
}

\section{$1 \quad$ Title and hypothesis}

I will take the title as suggested by the editors and reflect upon the relation between "design research" and "the methodological development of the discipline". Both concepts are not sufficiently clarified.

"Design Research" (Archer 1981) "... is systematic enquiry whose goal is knowledge of, or in, the embodiment of configuration, composition, structure, purpose, value and meaning in manmade things and systems."

Cross (1999: 6) suggests that:

"design research would therefore fall into three main categories, based on people, process and products:

- design epistemology - study of designerly ways of knowing

- design praxiology - study of the practices and processes of design

- design phenomenology - study of the form and configuration of artifacts."

And he emphasizes (1999: 7):

"... that we do not have to turn design into an imitation of science, nor do we have to treat design as a mysterious, ineffable art. ...

... we must avoid totally swamping our research with different cultures imported either from science or art. ..."

He calls this "designerly ways of knowing", claiming that design is a genuine way of knowledge production, different from science and art, which may lead to the "Sciences of the Artificial" (Simon 1969). So, since there is no substantial progress in defining design research, I will follow the concept of about / for / through, which - by means of "through" offers the semantic category of a designerly mode of knowledge production.

Regarding the "Methodological Development of the Discipline" one may ask: Towards which goal? Towards autonomous designerly ways of knowledge production? This, again, points to the concept of "research through design" (RTD). Before the further discussion of this concept (chapters 3, 4), here my hypothesis:

RTD provides the epistemological concepts for the development of a genuine design research paradigm, which is a condition for methodological development.

\section{Towards an own paradigm}

No doubt: there is progress in research about design as well as for design. But this does not essentially contribute to the development of design as a knowledge creating discipline. The challenge lies in the further clarification of RTD. What kind of process model, guiding research through design, might be able to provide something like "foundations"?

Fig. 1 (Jonas 1996) tells a story of design theory building: frequent disciplinary crises lead to the adoption of short-term design theories / -ideologies, which are able to displace the problem for a while through providing meaning and theoretical support for practice. On the other hand there are long-term theory-building activities that serve the same purpose but show 
considerable delay before they produce useful practical effects. We all know the big efforts in the 1960s. The immediate effects were rather negative and caused researchers as Alexander or Jones to retreat completely. Others saw their prejudices confirmed, because they did not want to believe in theory and methodology anyway. Nevertheless there are long-term effects such as this text.

Working on the basis of these short-term ideologies (currently: breathless research activities under mostly foreign standards) has the side-effect that proprietary theory-building is neglected. Competencies and academic incentives to follow this path autonomously become stunted under the compulsion of quick payoff. Other than in medicine - another "science of the artificial" aiming at purposeful action - the necessity of continuous theory work is hardly accepted in design. Theory-building (mostly about design) is left to those reflecting disciplines as philosophy, cultural studies, etc. that are only marginally interested in design's fitness for its essential function: the conception and projection of human conditions of living. Although the descent will be concealed for a while due to its economic relevance, this is a vicious circle, turning design into an appendix of marketing.

If design wants to strengthen its social and academic status, then it has to broaden its selfconception and to claim an appropriate share of the definition power regarding future conditions of living. An extended demand and a clearer concept of the own role will support theory-building again.

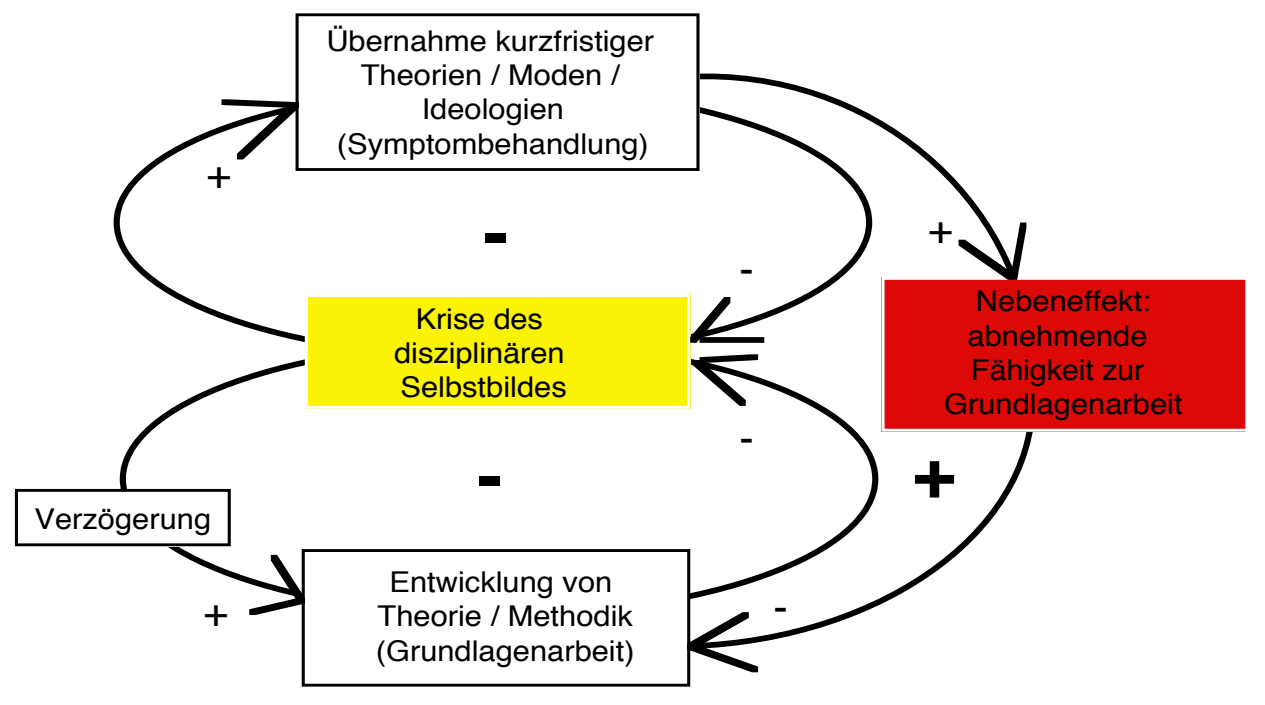

Fig. 1: Systemic archetype: "problem shift" from fundamental towards symptomatic approaches (Jonas 1996).

So, which are these "fundamental" approaches that support the construction of design methodology based upon the processual concept of RTD? The question is even more tantalising, since meanwhile we may know that there are no foundations comparable to those in the sciences, but at best a kind of anthropological basis, which can be described as a cybernetic learning mechanism of acting and reflecting.

We have to pursue "the paradox endeavour to design a foundation for a groundless field" (Jonas 2000), aiming at the development of an RTD paradigm. 


\section{$3 \quad$ Motivation and scope}

I am not aiming at grand new theory designs, but at the clarification of inconsistencies, references to developments and some further contributions. The focus, as stated above, is the concept of RTD, and the issue of dynamic / cybernetic "foundations" of this approach.

Since this is a Swiss publication, I start with Schneider (2006). His text "design as science and research", a hybrid of a political-strategic and scientific paper, asserts in a full-bodied and slightly simplifying manner, that design is a discipline, which "... auf Grundlagen beruht und sich somit durch fortschreitendes Wissen und Praxis auszeichnet" (... rests on foundations and is thus characterized by progressive knowledge and practice, W.J.). This refers to Friedman (2002), whose comprehension of foundations is in no way indiscutable. For example he strongly challenges the possibility of research "by" (through?) design, which Schneider accepts. Despite this ambiguity Schneider proclaims two main categories of design research: about / into and through design. This is defensible, of course, but what about research for design? I don't want to insist on the third category (maybe the former two provide contributions for design and thus implicitly include it), but this should be mentioned, at least.

Friedman's (2002) article is weak: it misquotes references, it neglects further clarifications and developments (Findeli, Jonas, etc.) and it finally returns to a kind of action - reflection approach, which comes close to what RTD could effectively mean. And I sense the article as slightly arrogant, because Friedman is teaching people about appropriate and inappropriate approaches and ways to read properly, while creating much of the confusion himself: $" \ldots$

Much of this confusion is linked to an ambiguous definition of design research proposed by Frayling in a 1993 paper. Frayling (1993) suggested that there are three models of design research, research into design, research by design, and research for design. Frayling is unclear about what "research by design" actually means and he seems never to have defined the term in an operational way. In a 1997 discussion (UK Council 1997: 21), he notes that it is "distantly derived from Herbert Read's famous teaching through art and teaching to art." This leads to serious conceptual problems.

... In addition to the difficulties this has caused in debates on the notion of the practice-based Ph.D., it also creates confusion for those who have come to believe that practice is research. The confusion rests, again, on a failure to read.

Beyond this arises the problem of what "research by design" might mean. If such a category did exist - and it may not - the fact of an existing category would tell us nothing of its contents....

While the phrase "research by design" has been widely used by many people, it has not been defined. I suspect, in fact, that those who use the phrase have not bothered to read either Frayling's (1993) paper or Read's $(1944,1974)$ book. Instead, they adopt a misunderstood term for its sound bite quality, linking it to an ill-defined series of notions that equate tacit knowledge with design knowledge, proposing tacit knowledge and design practice as a new form of theorizing.

While these problems are relatively inconsequential outside our field, it is important to understand that they exist if we are to develop a foundation for theory construction in design research. This is why I have given them so much thought."

"

Much thought! Frayling is ambiguous indeed (see chapter 4), but Friedman still increases confusion: Frayling (1993) did not speak of "research by design", but rather of "research through art and design". And he considered the category of "research for art and design" as the most problematic one, as it raises the issue of research being embodied in the artefact. So, 
which category does Friedman mean: Frayling's "through" or Frayling's "for"? And, who is to blame for their failures to read?

The following is not about Frayling's "through", but about Findeli's "through", which is different. And there is progress indeed in clarifying what RTD might be!

\section{Some clarifications}

Table 1 presents some "trinities" of design research concepts:

\begin{tabular}{|c|c|c|c|c|}
\hline & into / about & for / for & through / by & remarks \\
\hline $\begin{array}{l}\text { Frayling } \\
1993\end{array}$ & $\begin{array}{l}\text { into } \\
\text { "... the most straightforward, } \\
\text { and ... by far the most } \\
\text { common: } \\
\text { - Historical research } \\
\text { - Aesthetic or Perceptual } \\
\text { Research } \\
\text { - Research into a variety of } \\
\text { theoretical perspectives on } \\
\text { art and design - social, } \\
\text { economic, political, ethical, } \\
\text { cultural, iconographic, } \\
\text { technical, material, } \\
\text { structural... whatever. } \\
\text {... there are countless } \\
\text { models - and archives - } \\
\text { from which to derive its } \\
\text { rules and procedures." }\end{array}$ & $\begin{array}{l}\text { for } \\
\text { "The thorny one is Research } \\
\text { for art and design, ... . } \\
\text { Research where the end } \\
\text { product is an artefact - } \\
\text { where the thinking is, so to } \\
\text { speak, embodied in the } \\
\text { artefact, where the goal is } \\
\text { not primarily communicable } \\
\text { knowledge in the sense of } \\
\text { verbal communication, but } \\
\text { in the sense of visual or } \\
\text { iconic or imagistic } \\
\text { communication...." }\end{array}$ & $\begin{array}{l}\text { through } \\
\text { "... less straightforward, but } \\
\text { still identifiable and visible. } \\
\text { - materials research - such } \\
\text { as the titanium sputtering or } \\
\text { colorization of metal } \\
\text { projects ... } \\
\text { - development work - for } \\
\text { example, customizing a } \\
\text { piece of technology to do } \\
\text { something no-one had } \\
\text { considered before, and } \\
\text { communicating the results. } \\
\text {... } \\
\text { - action research - where a } \\
\text { research diary tells ... of a } \\
\text { practical experiment in the } \\
\text { studios, and the resulting } \\
\text { report aims to contextualize } \\
\text { it. Both the diary and the } \\
\text { report are there to } \\
\text { communicate the results, } \\
\text { which is what separates } \\
\text { research from the gathering } \\
\text { of reference materials...." }\end{array}$ & $\begin{array}{l}\text { Frayling's categorization is } \\
\text { inconsistent and rather } \\
\text { fuzzy: } \\
\text { Frayling's "through" } \\
\text { comprises much of Findeli's } \\
\text { "for"; only action research } \\
\text { may relate to "through / by" } \\
\text { with both authors. } \\
\text { Frayling's "for" is } \\
\text { something very } \\
\text { different from } \\
\text { Findeli's "for"; } \\
\text { Findeli would } \\
\text { probably not } \\
\text { consider it as } \\
\text { research at all. }\end{array}$ \\
\hline $\begin{array}{l}\text { Findeli } \\
1998\end{array}$ & $\begin{array}{l}\text { into / about } \\
\text { Separation of design } \\
\text { research and design practice } \\
\text { (weak theory), } \\
\text { "little or no contribution to a } \\
\text { theory of design", } \\
\text { see the field of "design } \\
\text { studies" (Margolin) }\end{array}$ & $\begin{array}{l}\text { for } \\
\text { Design as applied science } \\
\text { (no theory), } \\
\text { complex, sophisticated } \\
\text { projects } \\
\text { (Research and } \\
\text { Development) }\end{array}$ & $\begin{array}{l}\text { by / through } \\
\text { Conciliation of theory and } \\
\text { practice (strong theory) } \\
\text { embedded, implicated, } \\
\text { engaged, situated (Sartre, } \\
\text { Situationist) theory. } \\
\text { "Such research helps build a } \\
\text { genuine theory of design by } \\
\text { adopting an epistemological } \\
\text { posture more consonant } \\
\text { with what is specific to } \\
\text { design: the project." }\end{array}$ & $\begin{array}{l}\text { Findeli's } \\
\text { categorization } \\
\text { provides an } \\
\text { epistemologically } \\
\text { and semantically } \\
\text { much clearer } \\
\text { concept. }\end{array}$ \\
\hline $\begin{array}{l}\text { Jonas } \\
2004\end{array}$ & $\begin{array}{l}\text { about / über } \\
\text { "Research about Design } \\
\text { agiert von außen, den } \\
\text { Gegenstand auf Distanz } \\
\text { haltend. Forscher sind } \\
\text { wissenschaftlich arbeitende } \\
\text { Beobachter, die den } \\
\text { Gegenstand möglichst nicht } \\
\text { verändern. Beispiele: } \\
\text { Designphilosophie, } \\
\text { Designgeschichte, } \\
\text { Designkritik, ..." }\end{array}$ & $\begin{array}{l}\text { for / für } \\
\text { "Research for Design agiert } \\
\text { ebenfalls von außen, den } \\
\text { Prozess punktuell } \\
\text { unterstützend. Forscher } \\
\text { fungieren als } \\
\text { "Wissenslieferanten" für } \\
\text { Designer. Das bereitgestellte } \\
\text { Wissen hat aber durchaus } \\
\text { begrenzte Haltbarkeitsdauer, } \\
\text { weil es sich auf eine durch } \\
\text { Design zu verändernde } \\
\text { Wirklichkeit bezieht. } \\
\text { Beispiele: Marktforschung, } \\
\text { Nutzerforschung, ..., } \\
\text { Produktsemantik,..." }\end{array}$ & $\begin{array}{l}\text { through/ durch } \\
\text { "Research through Design } \\
\text { bezeichnet das designeigene } \\
\text { forschende und entwerfende } \\
\text { Vorgehen. Designer/ } \\
\text { Forscher sind unmittelbar } \\
\text { involviert, Verbindungen } \\
\text { herstellend, den } \\
\text { Forschungsgegenstand } \\
\text { gestaltend. Beispiele: } \\
\text { potentiell jedes "wicked } \\
\text { problem" im Rittelschen } \\
\text { (1992) Sinne." }\end{array}$ & $\begin{array}{l}\text { Jonas refers to } \\
\text { Findeli's } \\
\text { categorization. }\end{array}$ \\
\hline
\end{tabular}

Table 1: "Trinities" of design research concepts. 
The epistemological status of RTD is still weak, indeed. Grounded theory as well as action theory will probably contribute: Grounded theory is aiming at theory buildung, while accepting the modification of its subject matter. Action research is aiming at the modification of reality, while observing and processing theory modifications. Both approaches admit the involvement of the researcher as well as the emergence of theories from empirical data, in contrast to the traditional concept of theory building as the verification of previously formulated hypotheses.

Findeli (1998) argues that:

"... 'project-grounded research' ... is a kind of hybrid between action research and grounded theory research, but at the same time it reaches beyond these methods, in the sense that our researchers in design are valued both for their academic and professional expertise, which is not the case even in the most engaged action research situations. ...

... although the importance of the design project needs to be recognized in project-grounded research, it should never become the central purpose of the research project, otherwise we fall back into $R \& D$. Therefore, the design project and its output find their place in the annex of the dissertation, since practice is only a support for research (a means, not an end), the main product of which should remain design knowledge."

\section{The inconsistencies seem to result from the obvious shift of meaning of for and through between Frayling and Findeli. Again, this is about Findeli's RTD or 'project-grounded research'.}

\section{$5 \quad$ An anthropological assumption}

The ability to design and to be conscious about this (i.e. to be retrospective and projective regarding one's own position in the environment) distinguishes humans from the rest of the living world. The proper construction of this position and ability of acting in relation to nature is one of the unresolved challenges of modernity. According to Latour (1998) Boyle's Invention of the Laboratory and the Scientific Community as factory for the production of facts concerning nature adds to the transcendence of naturalised nature the immanence (feasibility) of socialised nature. Hobbes's Invention of Leviathan as representative of the unpredictable mass of citizens, seduced by their passions, adds to the immanence (mundane chaos) of the social the transcendence of a scientifically substantiated eternal order. It is thus that the 3 paradoxical constitutional guarantees of modernity arise:

1. Even when we construct nature, it is as if we did not.

2. Even when we do not construct society, it is as if we did.

3. Nature and society must remain absolutely separate; the work of purification must therefore remain separate from the mediation work.

Design, as the means, or the mediation work, cannot take part in the scientific endeavour of purification. It has to ignore the modern separation of nature and society. Conceiving and realising projects necessarily includes natural and social components. Even Simon (1996: 139-167), the protagonist of cognitive models, argues that design, seen as a socio-cultural phenomenon, follows evolutionary patterns and has no final goals. The intentional transfer of system states into preferred ones (state $1 \rightarrow$ state 2 ) opens up the hybrid field of the "Sciences of the Artificial". Management philosophy (Hayek 1967) has argued that the separation of natural and artificial is insufficient: there are systems, which are the outcomes of human 
activities, but not the results of human purpose. And of all things it is these delicate hybrid systems, which are the subjects of management and design interventions.

According to Rittel, these "wicked problems" can only be overcome by opening up the closed algorithmic problem solving process ( $1^{\text {st }}$ generation methods $)$ and initiating a process of argumentation and negotiation among the stakeholders ( $2^{\text {nd }}$ generation methods). In other words: he suggests a change from $1^{\text {st }}$ to $2^{\text {nd }}$ order observation: not systems are observed, but systems observing systems (von Foerster 1981). Under these conditions we have to account for the fact, that the problem itself is not "given", but will be designed by the stakeholders, and, in consequence, will change its character in the course of the solution process. No information is available, if there is no idea of a solution, because the questions arising depend on the kind of solution, which one has in mind. One cannot fully understand and formulate the problem, before it is solved. Thus, in the end, the solution is the problem. Therefore Rittel argues for the further development and refinement of the argumentative model of the design process and the study of the designers' reasoning, their rules of asking questions, generating information, and arriving at judgements. He concludes, slightly ironically (in Cross 1984: 326): "All of which implies a certain modesty; while of course on the other side there is a characteristic of the second generation which is not so modest, that of lack of respect for existing situations and an assumption that nothing has to continue to be the way that it is. That might be expressed in the principle of systematic doubt or something like it. The secondgeneration designer also is a moderate optimist, in that he refuses to believe that planning is impossible, although his knowledge of the dilemmas of rationality and the dilemmas of planning for others should tell him otherwise, perhaps. But he refuses to believe that planning is impossible, otherwise he would go home. He must also be an activist."

Jones (1970) puts it more general and metaphoric, when emphasizing the necessity of designing the design process itself. A considerable part of the design capacities has to be redirected from the problem to the process. The designer as "black box" (the artist) as well as the designer as "glass box" (the scientist, follower of $1^{\text {st }}$ generation methods) have to change their attitude towards a self-conception of designer as "self-organizing system", who is observing the evolving artefact plus himself observing the evolving artefact.

\section{Design ability is the essential human characteristic. It is the means for obtaining knowledge of the world. We cannot overcome our involvement in the process.}

\section{Evolutionary feedback patterns}

There is no evidence that socio-cultural processes follow a kind of plan or design. The concept of evolution appears to be promising for theoretical support and methodological progress. It relieves us from assuming an Intelligent Artificer at some mysterious point of origin. Utter undesignedness, pure chaos was the starting point, no more conditions, no foundations are required (Dennett 1995: 69):

"A designed thing, then, is either a living thing or a part of a living thing, or the artifact of a living thing, organized in any case in aid of this battle against disorder."

A good design theory, as a designed artefact, should be able to explain its own emergence.

And so far, Darwinian thinking provides the only descriptive model, which satisfies this selfreferential requirement. Other explanations would run into vicious circles or infinite regress. 
The epistemic nature of design can be considered as a learning process, which is biologically grounded in the need of organisms to survive in an environment. The aim cannot be final "true" representation of some external reality, but rather a process of (re-) construction for the purpose of appropriate (re-) action. Evolutionary epistemologists (Campbell 1974) argue, that the Kantian transcendental apriori has to be replaced by the assumption of an evolutionary fit between the objects and the subject of recognition. The evolutionary model of knowledge production suggests structural identity from the molecular up to the cognitive and cultural level (Riedl 2000). It reveals a circle of trial (based upon expectation) and experience (leading to success or failure, confirmation or refutation), or of action and reflection. Starting with passed cases, the circle consists of an inductive / heuristic semi-circle with purposeful learning from experience, leading to hypotheses and theories and prognoses about how the world works, and a deductive / logical semi-circle, leading to actions and interventions, which result in the confirmation or refutation of theories due to new experiences, etc. Internal or external perturbations (called ideas, creativity, or accidents, environmental changes, ...) influence the circle, leading to stabilizations (negative feedback) or amplifications and evolutionary change (positive feedback).

Only very recently this scheme was split into the "ratiomorphous" (Konrad Lorenz) systems of recognition and the rational systems of explanation / understanding, with its most extreme form: the logical positivist dualism of "context of discovery" (acting) vs. "context of justification" (thinking). While the ratiomorphous process of recognition has a high potential in dealing with complex, evolving phenomena, it is not always useful for causal explanations, and vice versa. But this "dilemma" is not inherent in the nature of knowledge production, but rather a consequence of the dualistic concept, which we have imposed on the process. Toulmin (2001) traces it back to the mid- $17^{\text {th }}$ century and distinguishes rationality from reasonableness, the latter loosing authority in the sciences. Language is too much locked in the "black\&white" tradition for distinguishing and indicating the beautiful transitory shades of "grey" between the poles of recognition and explanation.

\begin{tabular}{|l|l|}
\hline Recognition & Explanation \\
\hline - networks, many causes & - linear cause - effect relations \\
- simultaneous (simul hoc) & - sequential (propter hoc) \\
- 4 Aristotelian causes considered & - only causa efficiens considered \\
- only local validity, context is crucial & - global validity claimed, context excluded \\
- allows no experiments, mostly irreversible & - relies on experiments, mostly reversible \\
- prognosis is projection & - prognosis is forecasting \\
- correspondence of organism / artefact in a milieu & - coherence of elements inside a system \\
- reaches into high complexity & - reduces complexity \\
- fitness, "truth" means strong design & - "truth" means correct causal relations \\
- is labelled "pre-scientific" & - is labelled "scientific" \\
\hline
\end{tabular}

Table 2: Recognition vs. Explanation (Riedl 2000: 53-55).

The argument of naturalized epistemology appears in various forms. Dewey (1986) argues that processes of circular action, driven by intention, are the essential core of knowledge generation. The separation of thinking as pure contemplation and acting as bodily intervention into the world becomes obsolete; quite the reverse: Thinking depends on real world situations that have to be met. Thinking activity is initiated by the necessity to choose appropriate means with regard to expected consequences. The active improvement of an unsatisfactory situation is the primary motivation for thinking, designing, and, finally - in a more refined, purified, quantitative manner - for scientific knowledge production. According to Dewey, knowing is a manner of acting and "truth" is better called "warranted assertibility". Schön's (1983) epistemology of "reflective practice" can be regarded as the design-related description of 
these concepts. It might be this general pattern, which Cross (2001) characterizes as "designerly ways of knowing".

The theory of socio-cultural evolution seems to be a useful framework to denote the unpredictability of project outcomes, thus the limits of causal explanations, in a scientific manner. This is not to deny that designers are able to intentionally design and manufacture a new teapot, a new aircraft, or a new constitution. But these designs are temporal interventions into evolutionary processes. Most results disappear, a few are integrated into the further process. Failures as well as successes become part of the socio-cultural archive of mankind.

Evolutionary epistemology explains the ongoing production and re-production of both artefacts and knowledge, finally of design and science. There is no need for any specific nature of knowing in design.

\section{$7 \quad$ Variation - selection - re-stabilization}

Autopoietic systems show a high independence from internal and external perturbations (negative feedback compensates for the irritations). On the other hand circularity can cause so-called deterministic chaos. Minimal differences in initial conditions of the system parameters can cause completely different outcomes, so that predictability of final states is lost (positive feedback amplifies perturbations and triggers evolutionary change).

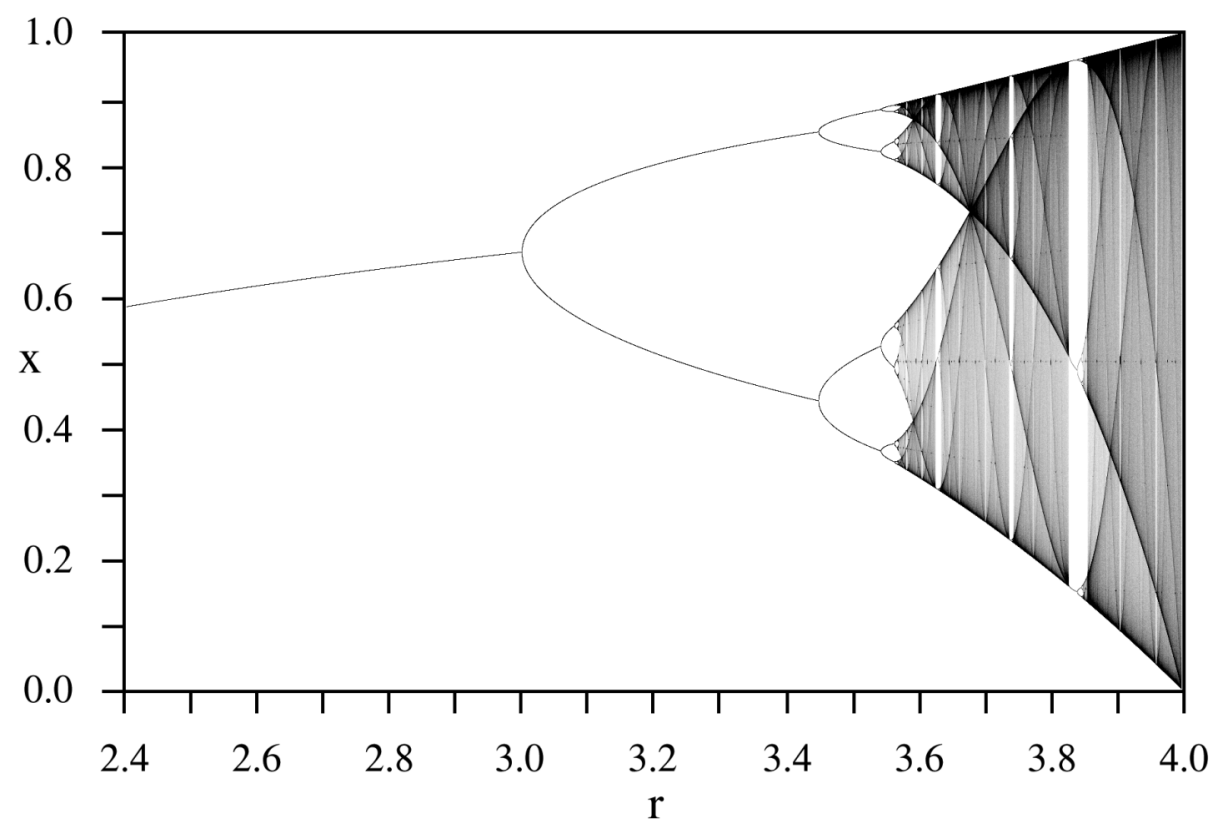

Fig. 2: Simple feedback processes, as in the logistic equation $x_{n+1}=r x_{n}\left(1-x_{n}\right)$, produce bifurcation cascades and deterministic chaos.

Natural evolutionary patterns of development, with their sequence of stable phases and sudden variations seem to be based on an interplay of negative and positive feedback mechanisms. The evolution of artefacts shows similar patterns (fig. 3). 


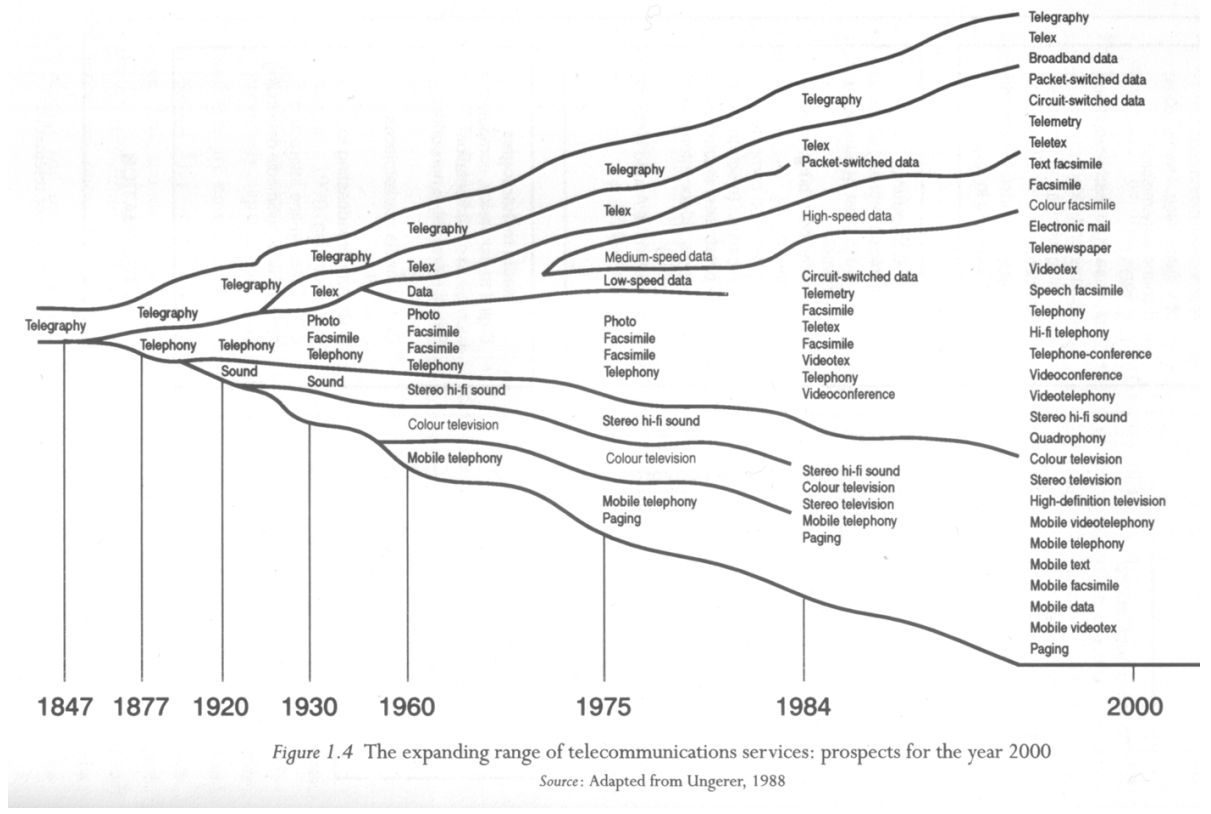

Fig. 3: Bifurcation patterns in the evolution of artefacts (Graham and Marvin 1996).

We seem to know where we come from, but we do not know, where we are going. At least we know the ancestors of our current artefacts, which means some interpretation capacity for design history. Nevertheless we normally do not know the influences that acted upon the bifurcation situations and resulted in exactly this and no other selection. Representations of design processes reveal these patterns too, which indicates similarity of ontogenetic and phylogenetic processes in designing (fig. 4).

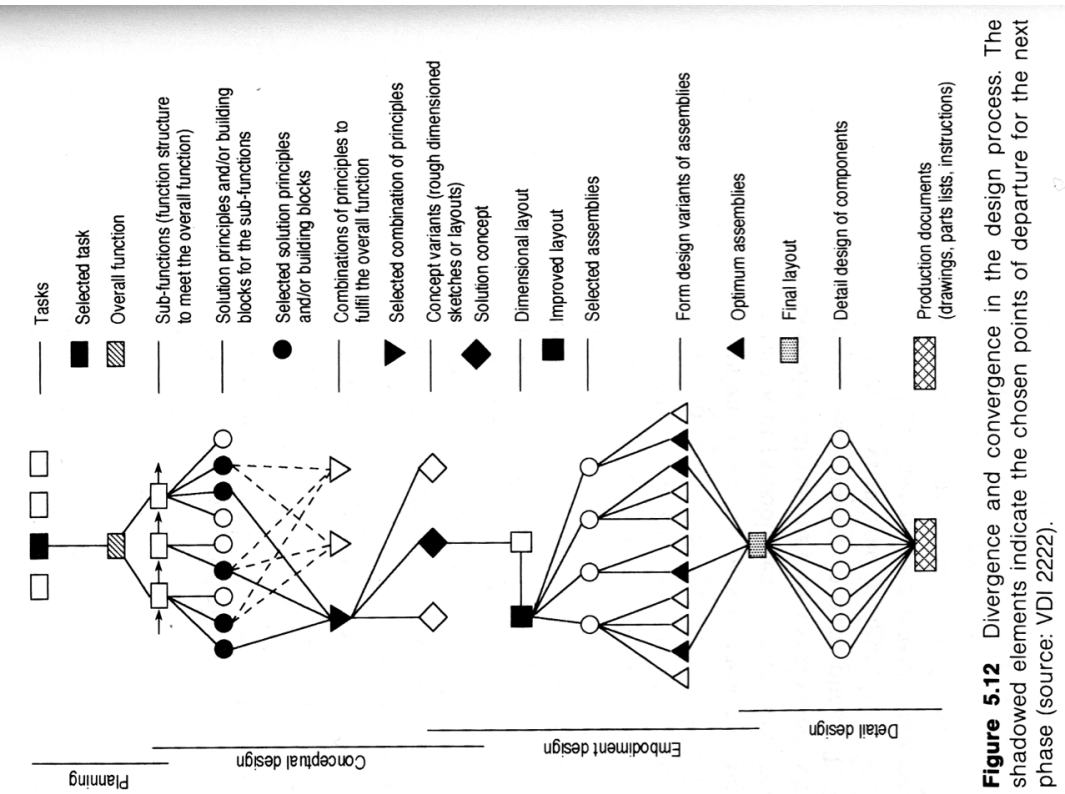

Fig. 4: Bifurcation cascades in the design process (Roozenburg and Eekels 1991).

The nicely cut branches after the bifurcations suggest the existence of rational criteria to overcome the indeterminacy, to take a decision, which provides more than a random chance of future viability. Rittel (1971/72: 48, 54, translation W.J.) comments this laconic: 
"Constrictions are not 'natural conditions' but deliberate restrictions of the variety of solutions, mostly implicit signs of resignation. ...

... In reality there is no opposition / sharp conflict between an ... intuitive approach to solve a problem and ... a controlled, reasonable and rational approach. The more control one wants to exert, the more well-founded one wants to judge, the more intuitive one has to be.

The endpoints in the more and more ramifying tree of causal explanations are always spontaneous judgements."

These evident analogies in the patterns of natural and artefact evolution confirm the use of evolutionary patterns in design theory. Luhmann's (1997) concept of social evolution is based upon the system / environment distinction; it is this difference, which enables evolution.

Evolution theory does not distinguish historical epochs, but the circular sequence of variation, selection, and re-stabilization. It explains the emergence of essential forms and substances from the accidental, relieving us of attributing the order of things to a form-giving telos or origin. It simply turns the terminological framework of world-description upside-down.

Evolution theory is not a theory of progress, and it does not deliver projections or interpretations of the future. Adaptation is a condition, not the goal or outcome of evolution: on the basis of being adapted it is possible to produce more and more risky ways of nonadaptation - as long as the continuation of autopoiesis is guaranteed.

The three processual components of evolution can be related to the constituent components of society, conceived as communicative system:

- Variation varies the elements of the systems, i.e. communications. Variation means deviating, unexpected, surprising communication. It may simply be questioning or rejecting expectations of meaning. Variation produces raw material and provides further communicative connections with wider varieties of meaning than before. In design this means new artefacts, conceived as materialized communication.

- Selection relates to the structures of the system. Structures determine the creation and use of expectations that determine communication processes. Positive selection means the choice of meaningful relations that promise a value for building or stabilizing structures. Selections serve as filters to control the diffusion of variations. Religion has been such a filter. Truth, money, power, as symbolically generalized media serve as filters in modern societies. In design this may be phenomena such as fashion or taste.

- Re-stabilization refers to the state of the evolving system after a positive / negative selection. It has to take care of the system-compatibility of the selection. Even negative selections have to be re-stabilized, because they remain in the system's memory / archive. In design this is the long-term viability of an artifact, in a functional as well as in a semantic sense.

This can be related to Langrish's (2004) memetic concept of recipemes / selectemes / explanemes as information units. And, more pragmatically, to Sanders (2006), who refers to the concept of usable / desirable / useful as success criteria. She argues that we are quite good in designing usability, make progress in designing desirability, and are still weak in designing usefulness. I agree with her diagnosis, but - before the evolutionary background - I am highly sceptical as to substantial progress regarding desirability or even usefulness.

If we are aiming at new descriptions and tools for the design process, we have to identify those patterns of natural evolution, which can be transferred to the evolution of artefacts: variation - selection - re-stabilization. 


\section{$8 \quad$ A generic design process model}

Design, as a sometimes highly rational endeavour, is embedded in overall trial\&error processes. It covers just the variation phase of socio-cultural evolution.

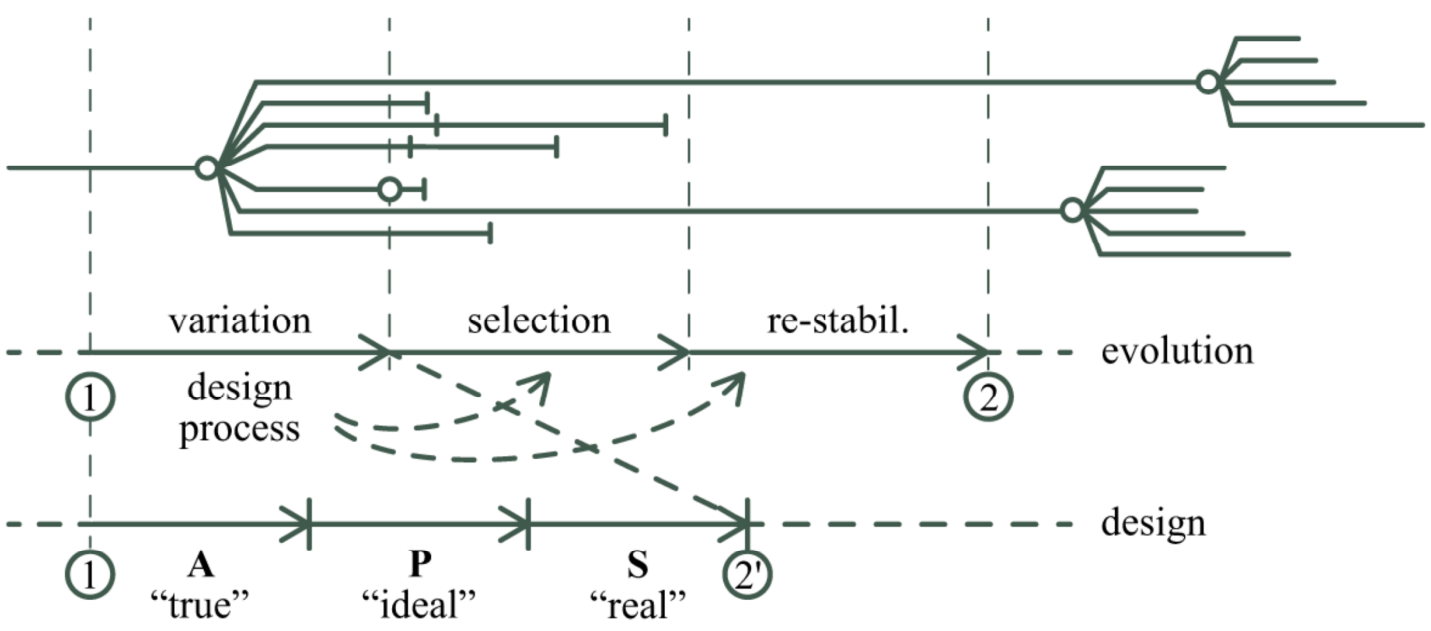

Fig. 5: The conscious design / learning process as part of the evolutionary trial\&error process.

Although design activities - by means of methods - desperately try to consider selection- and re-stabilization, they are necessarily de-coupled from these phases. There is no causal link between variation - selection - re-stabilization. Bringing a man to the moon may turn out as the first step into the universe, or as a singular historical event. So state 2 should better be labelled 2', leaving 2 for the actual future state, which cannot be determined. Design is about what is NOT (yet), which expresses the main epistemological problem the discipline has to face. The issue has been addressed by Nelson \& Stolterman (2003), who argue that design is an inquiry into three domains of knowing: the true, the ideal and the real, with incompatible ways of reasoning. The process model of ANALYSIS - PROJECTION - SYNTHESIS can be considered as a more pragmatic and operationalized version of the true / the ideal / the real (Jonas 1996).

The well-known circular design process models, prototypical the one of the Institute of Design Chicago (research - analysis - synthesis - realization), are adoptions of Kolb's (1984) "learning cycles". The latter, in turn, seems to relate to the basic cybernetic O.O.D.A. model of the USAF. They all neglect the long-term projective claim of design.

A combination of the macro model of ANALYSIS $\rightarrow$ PROJECTION $\rightarrow$ SYNTHESIS (domains of knowing) and the micro model of research $\rightarrow$ analysis $\rightarrow$ synthesis $\rightarrow$ realization (learning phases) provides a hypercyclic generic design process model (Hugentobler, Jonas, Rahe 2004). Hypercycles (Eigen and Schuster 1979) are basic process patterns at the transitory stage between chemical and biological evolution, in other words: explanations of the origin of life. The design argument becomes highly methaphoric here: Hypercyclic processes produce autopoietic closure. Feedback cycles describe prototypical learning processes of autopoietic systems. They produce patterns of deterministic chaos and evolutionary development. Natural and artificial evolution follow comparable processes. All this supports the concept of conscious design as necessarily embedded in evolutionary processes. Only the variation phase of artificial evolution is fully conscious and controllable. That means most of the time the "watchmaker" is actually blind (Dawkins 1986). He experiences some rare enlightened moments in an eternity of blindness. 


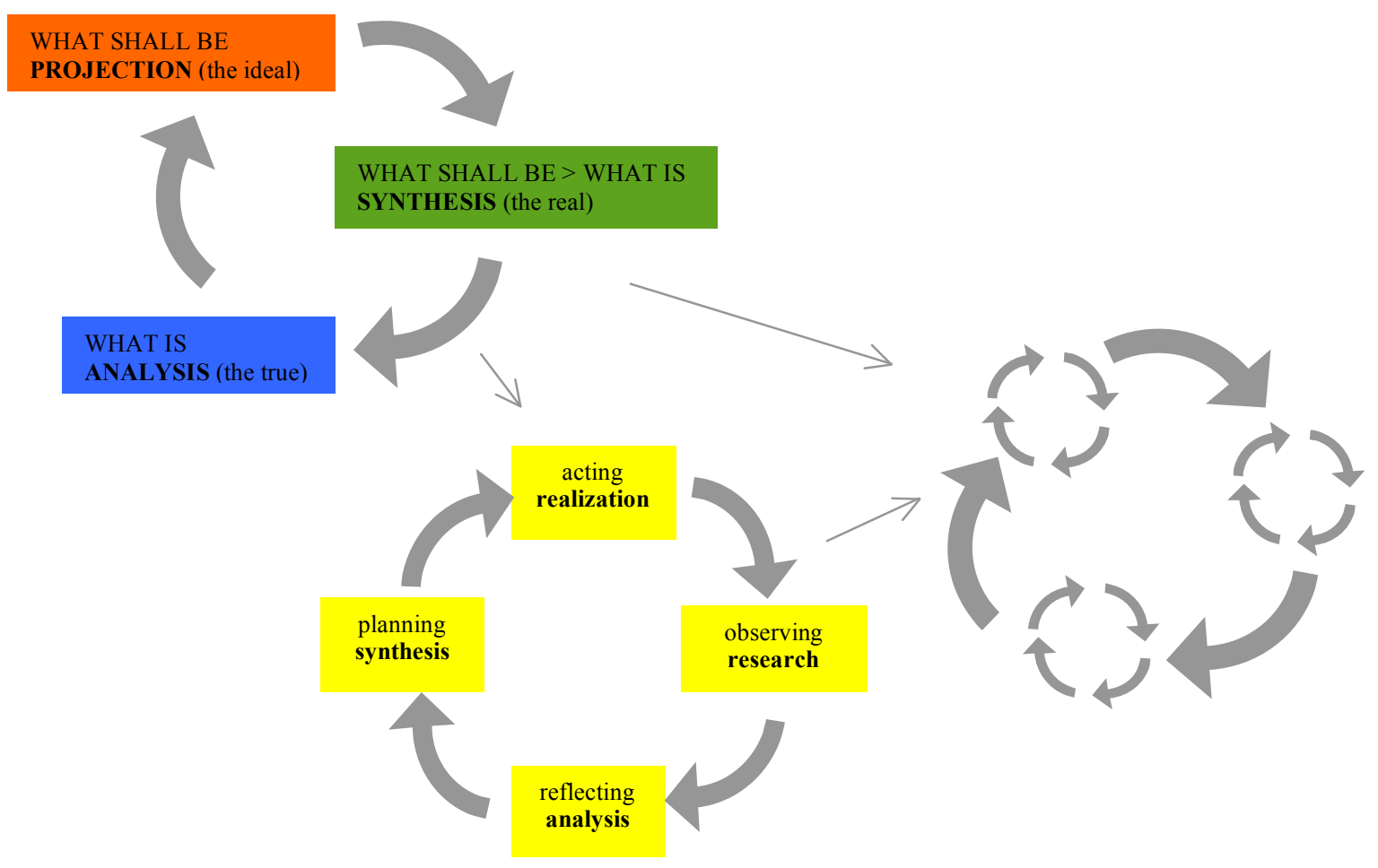

Fig. 6: Combining macro- and micro process provides a generic design process model.

If we switch from metaphor to operation, then we can interpret the hypercyclic scheme of the design process as a toolbox of 3 rows and 4 colums. Each of the 12 compartments that represent the complete process contains methods and tools for the respective process steps. If we assume 10 methods per compartment and 12 process steps, then we arrive at $10^{12}$ different paths / processes. Each path is a legitimate roadmap of the design process, transferring state 1 $\rightarrow$ state $2^{\prime}$. The scheme is open for various "flavours" of design research: technological, cultural, user-centred, semantic, systemic, ... and it is just one possible model of a process, the validity of which has to be debated elsewhere.

The distinction of design and research becomes fuzzy. The more one limits the inquiry to single domains of knowing or even to single process steps, the more it becomes possible and important to match the standards of scientific research. On the other hand, processes covering several boxes or even the whole process necessarily have to creatively deal with knowledge gaps (Jonas 2004).

The formulation of a genuine design research paradigm requires a generic design process model, which serves as a framework for RTD. It has to account for the (impossible but necessary) projective character of the project.

\section{Re-contextualizing the scientific paradigm}

Successful design depends on the variation phase of the evolutionary process. The following phases (selection, re-stabilization) are causally de-coupled. Scientific contributions may improve the probabilty of successful design, possibly. The field of HCI is facing similar problems. Fallman (2005) tries to clarify the role of design in HCI research and argues that "it makes more sense to regard HCI as a design discipline rather than as a more traditional 
academic research discipline." This is remarkable, since the design discipline on the other hand, is on the same road, but heading into the opposite direction, towards scientific research. Fallman distinguishes design and research in HCI as 2 poles of a continuum and coins the terms of "research-oriented design" and "design-oriented research", which can immediately be related to the present concepts of "research through design" and "design through research" (table 3).

\begin{tabular}{|l|l|r|}
\hline & Design $\leftarrow$ & \multicolumn{1}{|c|}{ Research } \\
\hline Fallman (for HCI) & $\begin{array}{l}\text { Research-oriented Design } \\
\text { Design is driven by research within a larger } \\
\text { design process } \\
\text { Aiming at the real, } \\
\text { by means of judgment and intuition, } \\
\text { judged by the Client }\end{array}$ & $\begin{array}{r}\text { Design-oriented Research } \\
\text { Research is driven by design within a larger } \\
\text { research process } \\
\text { Covering the whole situation / process } \\
\text { Aiming at the true, } \\
\text { building design as an institution for human- } \\
\text { centred innovation and supporting design as a } \\
\text { discipline }\end{array}$ \\
\hline
\end{tabular}

Table 3: Design and research in HCI and design, (Fallman 2005, Jonas 2006).

"Design through research" assumes that the "swampy lowlands" of uncertainty (Schön 1983) will be subsequently replaced by well-grounded knowledge. But exclusively scientific research is unable to fully recognize the implications of acting in a space of imagination and projection. The "knowledge base position" needs to be complemented by the "unknowledge base position" (Jonas, Chow, Verhaag 2005) or by the competencies to deal with not-knowing (Willke 2002). It is not science as a method, but science as a guiding paradigm for design, which is being called into question. Furthermore the hierarchical separation of basic / applied / clinical research does not make sense in this conception of design. Basic research for real needs has to be closely related to real-world situations. I.e. basic research, in order to be basic, has to be embedded / applied in clinical situations.

The idea of RTD is based upon a concept of domains of knowing and a generic structure of learning / designing, which has been derived from practice. Design process logic, according to the argument in this text, is a cybernetic logic of creating the objects of the world. Relevant design knowledge is not knowledge of the objects, but knowledge for the creation of the objects (Glanville 2006). Every design process (more or less) follows this generic structure, making use of the various (scientific) methods provided for each of the steps. The inherent fuzziness of the process model is able to bridge the causality gaps occurring between the different, often incompatible, scientific contributions. One might even go further, following Glanville (1980), and argue that RTD is the generic pattern for scientific research (aiming at purified, de-contextualized, generalizable, ... knowledge) as well as for artistic practice (aiming at undisciplined, subjective, singular, ... knowledge).

The hypothesis was: RTD provides the epistemological means for the development of a genuine design research paradigm. Now we have to do research about RTD, in order to better understand the process of RTD, research for RTD, in order to improve the process of RTD, and research through RTD, in order to establish and stabilize the disciplinary paradigm...

The Scientific Paradigm has to be embedded into the Design Paradigm: 


\section{Only design research conducted under the designerly paradigm can contribute to design's methodological development and its disciplinary stability / autonomy. Both depend on each other in a circular manner.}

\section{References}

Archer, Bruce (1981) "A View of the Nature of Design Research", in: R. Jacques and J. Powell (eds.) Design : Science : Method, Guildford, UK, Westbury House

Campbell, Donald T. (1960) "Blind Variation and Selective Retention in Creative Thought as in other Knowledge Processes", in: Psychological Review 67 (1960), pp 380-400

Cross, Nigel (ed.) (1984) Developments in Design Methodology, Chichester New York, John Wiley \& Sons

Cross, Nigel (1999) "Design research: A Disciplined Conversation", in: Design Issues Volume 15, Number 2, Summer 1999, 5-10

Cross, Nigel (2001) "Designerly Ways of Knowing: Design Discipline Versus Design Science", in: Design Issues Volume 17, Number 3 Summer 2001: 49-55

Dawkins, Richard (1986). The Blind Watchmaker New York: W. W. Norton \& Company

Dennett, Daniel C. (1995) Darwin's Dangerous Idea. Evolution and the Meanings of Life, London, Penguin Books

Dewey, John (1986) Logic: The Theory of Inquiry, Carbondale, Southern Illinois University Press

Fallman, Daniel (2005) "Why Research-oriented Design Isn't Design-oriented Research"; Proceedings of Nordes: Nordic Design Research Conference, May 29-31, Copenhagen, Denmark

Eigen, Manfred; Schuster, P. (1979) The Hypercycle. A Principle of Natural Self-Organization SpringerVerlag, Berlin / Heidelberg / New York

Findeli, Alain (1998) "A Quest for Credibility: Doctoral Education and Research in Design at the University of Montreal", in: Doctoral Education in Design, Ohio, Oct. 8-11, 1998

von Foerster, Heinz (1981) Observing Systems, Seaside, Cal.

Frayling, Christopher (1993) "Research in Art and Design", Royal College of Art Research Papers, Vol.1, No1, 1-5

Friedman, Ken (2002) "Theory Construction in Design research. Criteria, Approaches, and Methods.", in: Common Ground, Proceedings of the DRS International Conference, Brunel University, September 5-7, 2002 Glanville, Ranulph (1980) "Why Design Research?", in: Jacques, R.; Powell, A., Design: Science: Method, Guildford, Westbury House

Glanville, Ranulph (2006) "Construction and Design", in: Constructivist Foundations 2006, vol. I, no. 3 Hayek, F.A. von (1967) "The Results of Human Action but not of Human Design", in: Hayek, Studies in Philosophy, Politics and Economics, Chicago

Hugentobler, Hans Kaspar; Jonas, Wolfgang; Rahe, Detlef (2004) "Designing a Methods Platform for Design and Design Research", in: futureground, DRS International Conference, Melbourne, Nov. 2004 Jonas, Wolfgang

- (1994) Design - System - Theorie. Überlegungen zu einem systemtheoretischen Modell von Designtheorie, Essen, Verlag die Blaue Eule

- (1996) "Design als systemische Intervention - für ein neues (altes) "postheroisches" Designverständnis," in: 17. designwissenschaftliches Kolloquium "Objekt und Prozeß", 28.-30.11.1996, Burg Giebichenstein, Halle / Saale - (2000) "The paradox endeavour to design a foundation for a groundless field", in: Proceedings of International Conference on Design Education, 12/2000, Curtin University, Perth, Australia

- (2004) "Forschung durch Design", Tagung des Swiss Design Network, Basel 05/2004

- (2006) "Research through DESIGN through research - a problem statement and a conceptual sketch", in: Proceedings of wonderground, DRS international conference, Lisbon 11/2006)

- (2007) "Research through DESIGN through research - a cybernetic model of designing design foundations", submitted to Kybernetes (special issue on cybernetics and design)

Jonas, Wolfgang; Chow, Rosan; Verhaag, Niels (2005) Proceedings of EAD06 http://ead06.hfk-bremen.de Jonas, Wolfgang; Meyer-Veden, Jan (2004) Mind the gap! - on knowing and not - knowing in design, Bremen, Hauschild-Verlag

Jones, John Christopher (1970, 1992) Design Methods. Seeds of human futures, London, John Wiley \& Sons, second edition, Van Nostrand Reinhold, New York 1992

Kolb, David A. (1984) Experiential Learning: Experience as the Source of Learning and Development, ... Langrish, John Z. (2004) "Darwinian Design: The Memetic Evolution of Design Ideas", in: Design Issues: Volume 20, Number 4 Autumn 2004 pp 4-19

Latour, Bruno (1998) Wir sind nie modern gewesen. Versuch einer symmetrischen Anthropologie, 
Frankfurt/M., Fischer (frz. Original 1991)

Logistic equation http://de.wikipedia.org/wiki/Logistische Gleichung (03 Jan. 2007)

Luhmann, Niklas (1997) Die Gesellschaft der Gesellschaft, Frankfurt / Main, Suhrkamp

Nelson, Harold G.; Stolterman, Erik (2003) The Design Way. Intentional Change in an Unpredictable World, Englewood Cliffs, New Jersey, Educational Technology Publications

O.O.D.A. http://de.wikipedia.org/wiki/OODA-Loop (03 Jan. 2007)

Riedl, Rupert (2000) Strukturen der Komplexität. Eine Morphologie des Erkennens und Erklärens, Berlin Heidelberg New York, Springer

Rittel, Horst W. J (1972) "Second-generation Design Methods", in: Cross, Nigel (ed.) Developments in Design Methodology, John Wiley, Chichester 1984: 317-327 (Original 1972)

Roozenburg, N.F.M.; Eekels, J. (1995) Product Design: Fundamentals and Methods, Chichester, John Wiley \& Sons

Sanders, Elizabeth (2006) "Design Research in 2006", in: Design Research Quarterly, V.I:1 September 2006

Schneider, Beat (2006) Design als Wissenschaft und Forschung, präsentiert zur Tagung der DGTF, Berlin, Mai 2006

Schön, Donald A. (1983) The Reflective Practitioner. How Professionals Think in Action, Basic Books

Simon, Herbert A. (1969, 1981, 1996) The Sciences of the Artificial, Cambridge, Mass., MIT Press

Toulmin, Stephen (2001) Return to Reason, Cambridge, MA, Harvard University Press

Willke, Helmut (2002) Dystopia. Studien zur Krisis des Wissens in der modernen Gesellschaft, Frankfurt / M., Suhrkamp 